\title{
Universal Stress Proteins Contribute Edwardsiella ictaluri Virulence in Catfish
}

\author{
Ali Akgul, Seong Won Nho, Safak Kalindamar, Hasan C. Tekedar, Hossam Abdalhamed, \\ Mark L. Lawrence and Attila Karsi*
}

OPEN ACCESS

Edited by:

Martin Stephen LLewellyn,

University of Glasgow,

United Kingdom

Reviewed by:

Ulisses Padua Pereira

Universidade Estadual de Londrina,

Brazil

Hetron Mweemba Munang'andu, Norwegian University of Life Sciences,

Norway

${ }^{*}$ Correspondence: Attila Karsi

karsi@cvm.msstate.edu

Specialty section:

This article was submitted to

Aquatic Microbiology,

a section of the journal

Frontiers in Microbiology

Received: 11 May 2018

Accepted: 14 November 2018

Published: 28 November 2018

Citation:

Akgul A, Nho SW, Kalindamar S,

Tekedar HC, Abdalhamed $\mathrm{H}$

Lawrence ML and Karsi A (2018)

Universal Stress Proteins Contribute

Edwardsiella ictaluri Virulence

in Catfish. Front. Microbiol. 9:2931.

doi: 10.3389/fmicb.2018.02931
Department of Basic Sciences, College of Veterinary Medicine, Mississippi State University, Starkville, MS, United States

Edwardsiella ictaluri is an intracellular Gram-negative facultative pathogen causing enteric septicemia of catfish (ESC), a common disease resulting in substantial economic losses in the U.S. catfish industry. Previously, we demonstrated that several universal stress proteins (USPs) are highly expressed under in vitro and in vivo stress conditions, indicating their importance for E. ictaluri survival. However, the roles of these USPS in E. ictaluri virulence is not known yet. In this work, 10 usp genes of E. ictaluri were in-frame deleted and characterized in vitro and in vivo. Results show that all USP

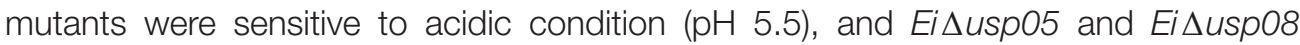
were very sensitive to oxidative stress $\left(0.1 \% \mathrm{H}_{2} \mathrm{O}_{2}\right)$. Virulence studies indicated that Ei $\Delta u s p 05$, Ei $\Delta u s p 07$, Ei $\Delta u s p 08$, Ei $\Delta u s p 09$, Ei $\Delta u s p 10$, and Ei $\Delta u s p 13$ were attenuated significantly compared to E. ictaluri wild-type (EIWT; 20, 45, 20, 20, 55, and 10\% vs. $74.1 \%$ mortality, respectively). Efficacy experiments showed that vaccination of catfish

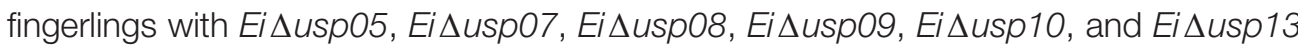
provided complete protection against EIWT compared to sham-vaccinated fish ( $0 \%$ vs. $58.33 \%$ mortality). Our results support that USPs contribute E. ictaluri virulence in catfish.

Keywords: stress, ESC, USP, mutation, vaccine

\section{INTRODUCTION}

Enteric septicemia of channel catfish (ESC) is one of the most prevalent diseases of cultured catfish, causing significant losses (USDA, 2014). The most common practice in ESC treatment is use of feed medicated with oxytetracycline, sulfadimethoxine, or florfenicol. However, one of the earliest clinical signs of ESC is reduced appetite. Thus, these antimicrobials are only useful in limiting the spread of an outbreak and rather than treating the disease. Also, medicated feed may lead to the emergence of resistant Edwardsiella ictaluri strains (Tu et al., 2008).

The universal stress proteins (USP) have a conserved domain of 140-160 amino acids, and are present in archaea, bacteria, and plants (Nachin et al., 2005), but not in animals and human (Siegele, 2005). In Escherichia coli usp are involved in various functions from oxidative stress to adhesion and motility (Nachin et al., 2005). Under stress, USPs are overproduced and through a variety of mechanisms aid the survival of organism in stressful conditions (Heermann et al., 2009b). The uspA mutation caused decreased survival in E. coli (Tkaczuk et al., 2013). It is known that USPs are needed by pathogens (Hensel, 2009). USPs affect persistence and survival of Mycobacterium tuberculosis (Hingley-Wilson et al., 2010), and cause growth arrest and reduce the virulence in 
Salmonella typhimurium C5 (Liu et al., 2007) and Burkholderia pseudomallei (Al-Maleki et al., 2014). USPs are also necessary for the intracellular growth adaption of Listeria monocytogenes (Chatterjee et al., 2006). Similarly, Staphylococcus aureus virulence factors were downregulated in vivo while expression of uspA increased (Chaffin et al., 2012). Acinetobacter baumannii uspA is essential in pneumonia and pathogenesis (Elhosseiny et al., 2015).

Although increased expression of several usp genes in E. ictaluri under various stressors has been reported (Akgul et al., 2018), the role of USPs in E. ictaluri virulence is not known yet. Therefore, in this study, 10 E. ictaluri usp genes were studied by introducing in-frame deletions and determining their survival under acidic and oxidative stress conditions. Also, the virulence and protective properties of mutants against ESC infection were tested in catfish fingerlings.

\section{MATERIALS AND METHODS}

\section{Animals}

All fish experiments were performed based on a protocol approved by the Mississippi State University Institutional Animal Care and Use Committee (protocol number 15-043). Channel catfish fingerlings were obtained from the fish hatchery at the College of Veterinary Medicine, Mississippi State University, and maintained at $25-28^{\circ} \mathrm{C}$ during experiments. Tricaine methanesulfonate (MS-222, Western, Chemical, Inc.) was used to sedate $(100 \mathrm{mg} / \mathrm{ml})$ or euthanize $(400 \mathrm{mg} / \mathrm{ml})$ the catfish.

\section{Bacterial Strains, Plasmids, and Growth Conditions}

Bacterial strains and plasmids used in this work are listed in Table 1. E. ictaluri $93-146$ wild-type (WT) was grown at $30^{\circ} \mathrm{C}$ using Brain Heart Infusion (BHI) broth and agar (Difco, Sparks, $\mathrm{MD}$, United States). E. coli strains were cultured at $37^{\circ} \mathrm{C}$ using Luria-Bertani (LB) broth and agar (Difco). E. coli CC118 $\lambda$ pir

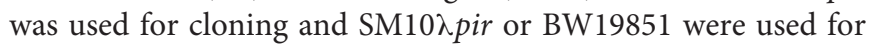
transferring pMEG-375 or pAKgfplux1 into E. ictaluri. When required, the following antibiotics and reagents (Sigma-Aldrich, Saint Louis, MN, United States) were added to culture medium at the following concentrations: ampicillin (Amp: $100 \mu \mathrm{g} / \mathrm{ml}$ ), colistin (Col: $12.5 \mu \mathrm{g} / \mathrm{ml}$ ), sucrose (5\%), and mannitol (0.35\%).

\section{Construction of In-Frame Deletion Mutants}

The nucleotide sequences of 10 E. ictaluri usp genes were obtained from the E. ictaluri 93-146 genome (GenBank accession: CP001600), and four primers were designed for each gene (Tables 2, 3). Restriction sites were included in forward and reverse primers. Overlap extension PCR was used to delete the functional usp genes from the E. ictaluri genome (Horton et al., 1990). Genomic DNA was isolated from E. ictaluri using a DNeasy Blood \& Tissue Kit (Qiagen, Valencia, CA, United States) and used as template in PCR. The upstream and downstream
TABLE 1 | Bacterial strains and plasmids used in this study.

\begin{tabular}{|c|c|c|}
\hline Strain & Relevant characteristics & Reference \\
\hline \multicolumn{3}{|l|}{$\begin{array}{l}\text { Edwardsiella } \\
\text { ictaluri }\end{array}$} \\
\hline $93-146$ & Wild type; pEl1+; pEI2+; Colr & Lawrence et al., 1997 \\
\hline Eidusp02 & $\begin{array}{l}\text { 93-146 derivative; pEl1+; } \\
\mathrm{pEI} 2+; \text { Colr; } \Delta \text { usp02 }\end{array}$ & This study \\
\hline Eisusp03 & $\begin{array}{l}\text { 93-146 derivative; pEl1+; } \\
\text { pEI2+; Colr; } \Delta \text { usp03 }\end{array}$ & This study \\
\hline Eisusp04 & $\begin{array}{l}\text { 93-146 derivative; pEl1+; } \\
\text { pEl2+; Colr; } \Delta \text { usp04 }\end{array}$ & This study \\
\hline Ei $\Delta u s p 05$ & $\begin{array}{l}\text { 93-146 derivative; pEl1+; } \\
\text { pEl2+; Colr; } \Delta \text { usp05 }\end{array}$ & This study \\
\hline Eisusp06 & $\begin{array}{l}\text { 93-146 derivative; pEl1+; } \\
\text { pEl2+; Colr; } \Delta \text { usp06 }\end{array}$ & This study \\
\hline Eidusp07 & $\begin{array}{l}\text { 93-146 derivative; pEl1+; } \\
\text { pEl2+; Colr; } \Delta \text { usp07 }\end{array}$ & This study \\
\hline Eisusp08 & $\begin{array}{l}\text { 93-146 derivative; pEl1+; } \\
\text { pEl2+; Colr; } \Delta \text { usp08 }\end{array}$ & This study \\
\hline Eisusp09 & $\begin{array}{l}\text { 93-146 derivative; pEl1+; } \\
\text { pEl2+; Colr; } \Delta \text { usp09 }\end{array}$ & This study \\
\hline Eidusp10 & $\begin{array}{l}\text { 93-146 derivative; pEl1+; } \\
\text { pEl2+; Colr; } \Delta \text { usp } 10\end{array}$ & This study \\
\hline Eidusp13 & $\begin{array}{l}\text { 93-146 derivative; pEl1+; } \\
\text { pEI2+; Colr; } \Delta \text { usp } 13\end{array}$ & This study \\
\hline \multicolumn{3}{|c|}{ Escherichia coli } \\
\hline CC118גpir & $\begin{array}{l}\text { D(ara-leu); araD; DlacX74; } \\
\text { galE; galK; phoA20; thi-1; } \\
\text { rpsE; rpoB; argE(Am); recAl; } \\
\text { IpirR6K }\end{array}$ & Herrero et al., 1990 \\
\hline SM10גpir & $\begin{array}{l}\text { thi; thr; leu; tonA; lacY; supE; } \\
\text { recA;::RP4-2-Tc::Mu; Kmr; } \\
\text { IpirR6K }\end{array}$ & $\begin{array}{l}\text { Miller and Mekalanos, } \\
1988\end{array}$ \\
\hline 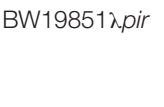 & $\begin{array}{l}\text { RP4-2 (Km::Tn7, Tc::Mu-1), } \\
\text { DuidA3::pir+, recA1, endA1, } \\
\text { thi-1, hsdR17, creC510 }\end{array}$ & Metcalf et al., 1994 \\
\hline \multicolumn{3}{|l|}{ Plasmids } \\
\hline pMEG-375 & $\begin{array}{l}8142 \text { bp, } \mathrm{Amp}^{r}, \mathrm{Cm}^{\mathrm{r}} \text {, lacZ, } \\
\text { R6K ori, mob incP, sacR sacB }\end{array}$ & Dozois et al., 2003 \\
\hline pAKgfplux1 & $\begin{array}{l}5681 \text { bp, Pstl, EcoRl, Hpal, } \\
\text { Asel, BstBl }\end{array}$ & Karsi et al., 2006 \\
\hline $\mathrm{pEi \Delta usp02}$ & $\begin{array}{l}9939 \text { bp, } \Delta \text { usp02, } \\
\text { pMEG-375 }\end{array}$ & This study \\
\hline $\mathrm{p} E i \Delta u s p 03$ & $\begin{array}{l}9960 \text { bp, } \Delta \text { uspo3, } \\
\text { pMEG-375 }\end{array}$ & This study \\
\hline $\mathrm{pEi \Delta usp04}$ & $\begin{array}{l}10096 \mathrm{bp}, \Delta \text { usp04, } \\
\text { pMEG-375 }\end{array}$ & This study \\
\hline $\mathrm{pEi} \Delta$ usp05 & $\begin{array}{l}10080 \text { bp, } \Delta \text { usp05, } \\
\text { pMEG-375 }\end{array}$ & This study \\
\hline $\mathrm{p} E i \Delta u s p 06$ & $\begin{array}{l}10101 \mathrm{bp}, \Delta \text { uspo6, } \\
\text { pMEG-375 }\end{array}$ & This study \\
\hline $\mathrm{pEi} \Delta$ usp07 & $\begin{array}{l}10026 \text { bp, } \Delta \text { usp07, } \\
\text { pMEG-375 }\end{array}$ & This study \\
\hline $\mathrm{pEi} \Delta$ usp08 & $\begin{array}{l}10087 \text { bp, } \Delta \text { usp08, } \\
\text { pMEG-375 }\end{array}$ & This study \\
\hline $\mathrm{p} E i \Delta u s p 09$ & $\begin{array}{l}9843 \text { bp, susp09, } \\
\text { pMEG-375 }\end{array}$ & This study \\
\hline $\mathrm{pEi} \Delta \mathrm{usp} 10$ & $\begin{array}{l}9795 \mathrm{bp}, \Delta u s p 10 \\
\text { pMEG-375 }\end{array}$ & This study \\
\hline $\mathrm{pEi} \Delta \mathrm{usp} 13$ & $\begin{array}{l}9975 \mathrm{bp}, \Delta u s p 13 \\
\text { pMEG-375 }\end{array}$ & This study \\
\hline
\end{tabular}


TABLE 2 | The primers used for mutant construction and sequence validation.

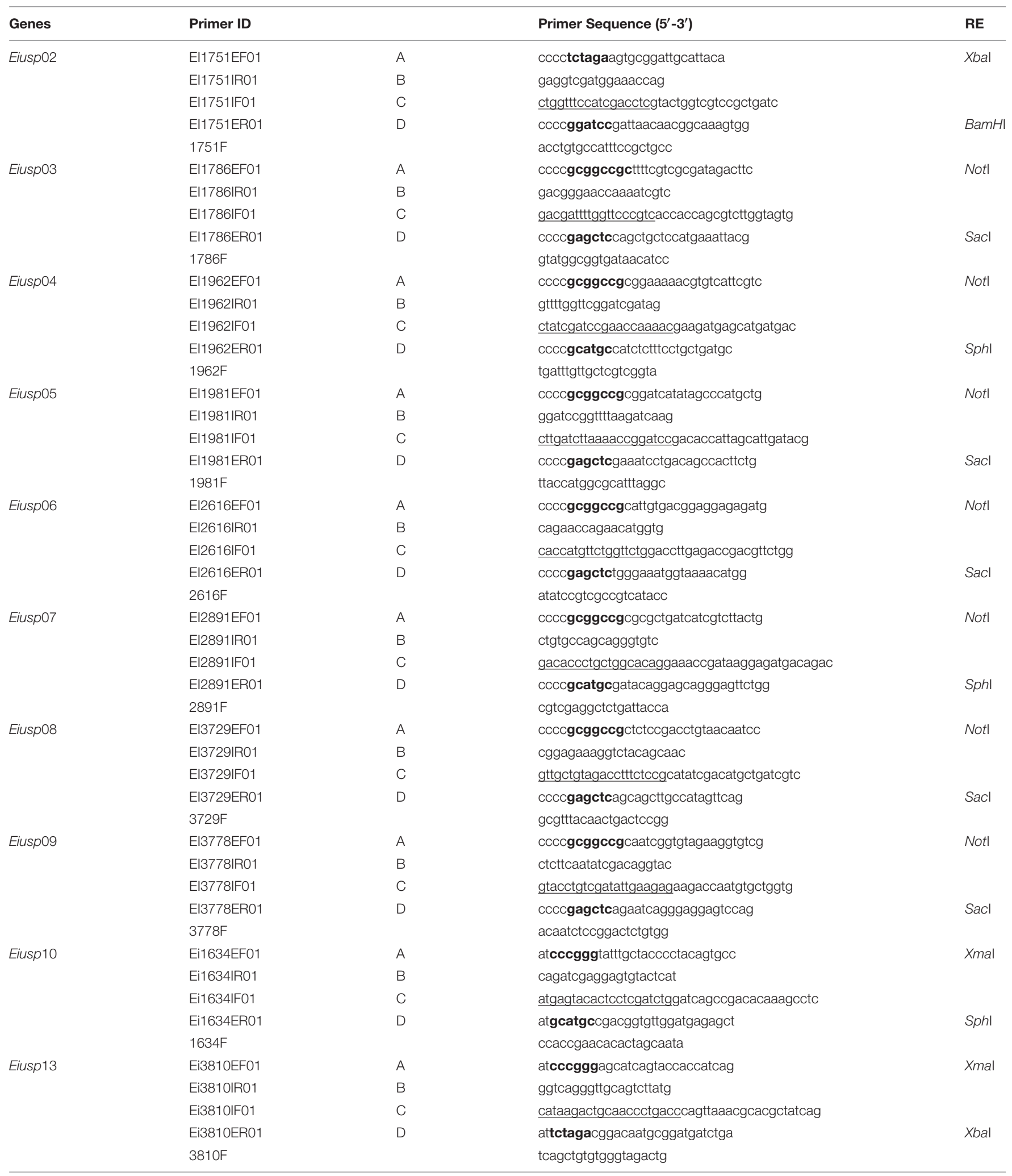

Primers $A, B, C$, and $D$ were used for mutant construction. Bold letters show restriction enzymes added to $A$ and $D$ primers. Underlined letters in primer $C$ indicate reverse complemented primer $B$ sequence. The last primer in each group used for sequence confirmation. 


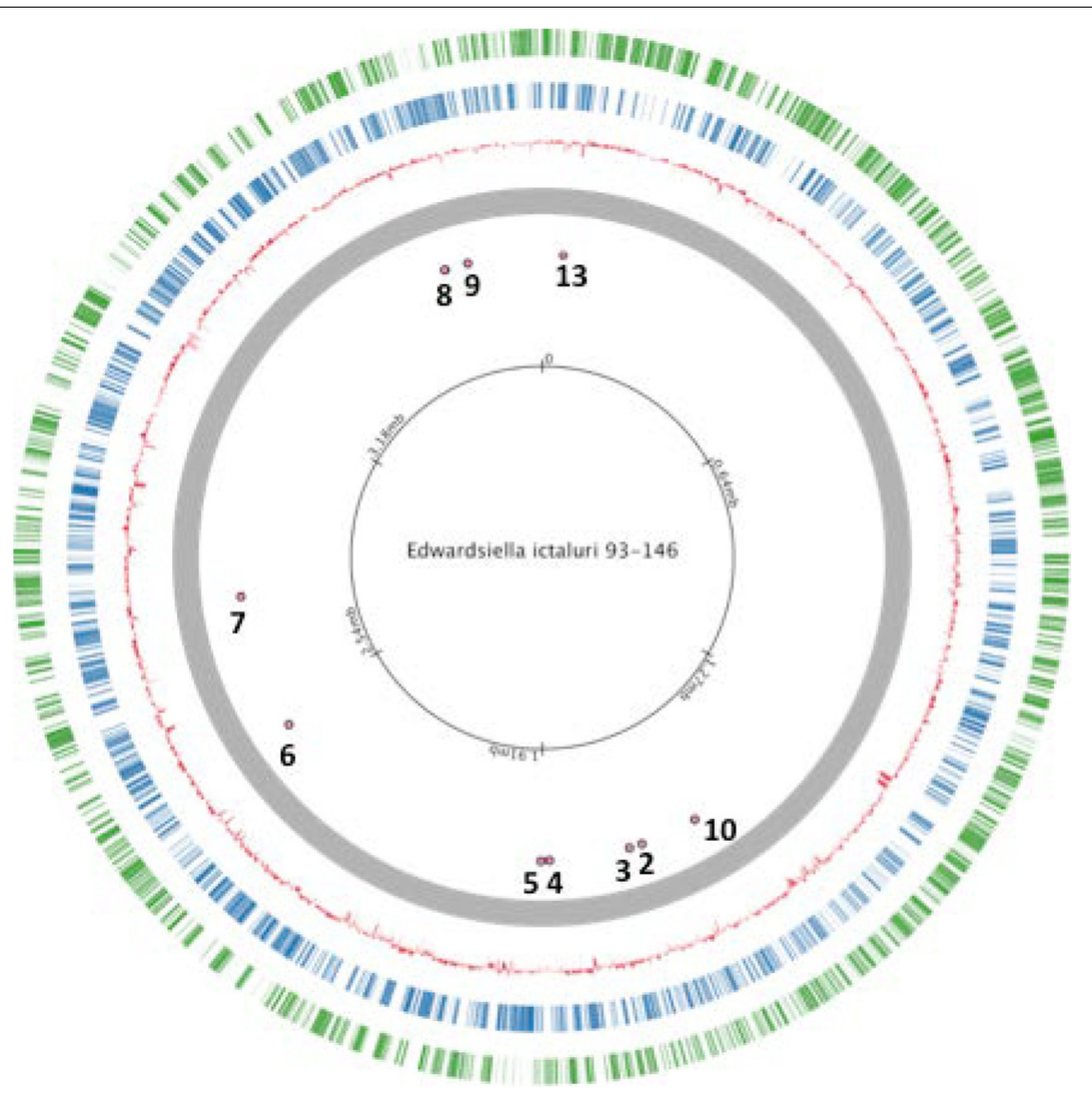

FIGURE 1 | Locations of studied universal stress proteins in Edwardsiella ictaluri strain 93-146 genome.

regions of each gene were amplified, and products were gelextracted using a QIAquick Gel Extraction Kit (Qiagen). The amplified upstream and downstream fragments were mixed equally and used as a template in the subsequent overlap extension PCR to generate the in-frame deletion fragment for each gene. The in-frame deletion fragments were digested with appropriate restriction enzymes (NEB) (Table 2) and cleaned up. The suicide plasmid pMEG-375 was purified from an overnight

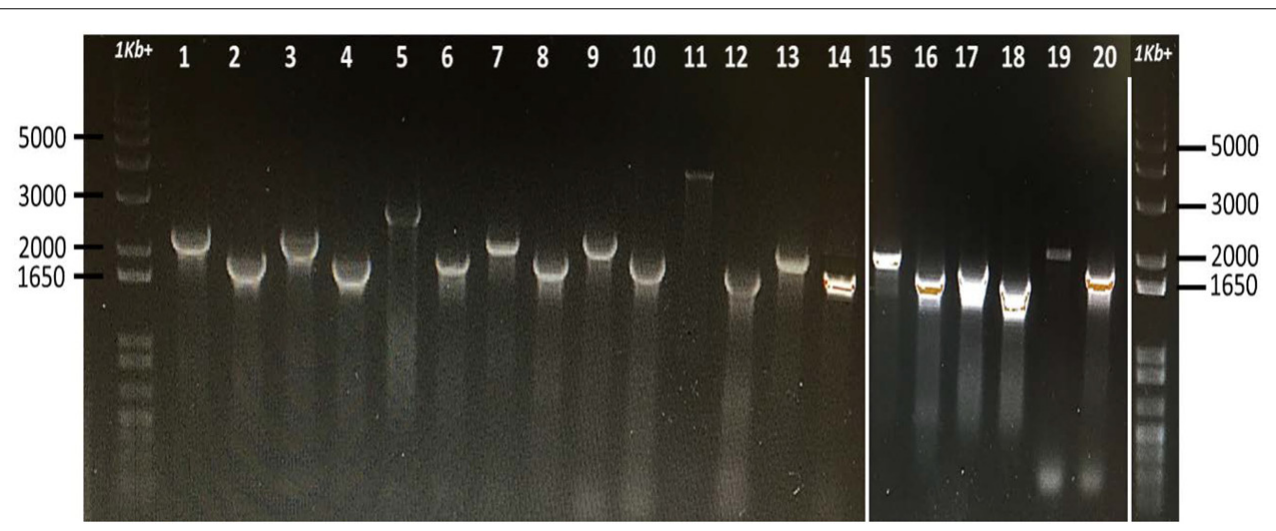

FIGURE 2 | Confirmation of E. ictaluri USP mutants by using forward (A) and reverse (D) primers. Fragments were amplified from mutant and wild-type strains and separated on two different $1 \%$ agarose gels, which were then combined (white lines above indicate joints). A $1 \mathrm{~Kb}+$ marker lane was also added to the end. Lane 1 , EIWT (usp02) and lane 2, Ei $\Delta$ usp02; lane 3, EiWT (usp03) and lane 4, Ei $\Delta$ usp03; lane 5, EMT (usp04) and lane 6, Ei $\Delta$ usp04; lane 7 is EIWT (usp05) and lane 8, Ei $\Delta$ usp05; lane 9 is EWT (usp06) and lane 10 is Ei $\Delta$ usp06; lane 11 is EWT (Usp07) and lane 12 is Ei $\Delta$ usp07; lane 13 is EMT (usp08) and lane 14 is Ei $\Delta$ usp08; lane 15 is EIWT (usp09) and lane 16 is Ei $\Delta u s p 09$; lane 17 is EiWT (usp10) and lane 18 is Ei $\Delta u s p 10$; lane 19 is EiWT (usp13) and lane 20 is Ei $\Delta$ usp13. 
TABLE 3 | Summary of E. ictaluri usp genes and in-frame deletion.

\begin{tabular}{|c|c|c|c|c|c|c|}
\hline Gene & Locus ID & Gene ID & ORF size (bp) & Remaining US ORF (bp) & Remaining DS ORF (bp) & Deleted ORF (bp)/(\%) \\
\hline usp02 & NT01El_1751 & $u s p F$ & 435 & 15 & 0 & 420/(97) \\
\hline usp03 & NT01El_1786 & - & 432 & 8 & 6 & 418/(97) \\
\hline usp04 & NT01EI_1962 & uspE & 960 & 28 & 6 & $926 /(96)$ \\
\hline usp05 & NT01El_1981 & uspA & 417 & 24 & 21 & $372 /(89)$ \\
\hline usp06 & NT01El_2616 & uspA & 420 & 12 & 14 & $394 /(94)$ \\
\hline usp07 & NT01El_2891 & $k d p D$ & 2709 & 30 & 9 & 2670/(99) \\
\hline usp08 & NT01EI_3729 & uspA & 438 & 12 & 27 & 399/(91) \\
\hline uspo9 & NT01EI_3778 & uspA & 429 & 18 & 12 & 399/(93) \\
\hline usp10 & NT01EI_1634 & - & 258 & 0 & 9 & 249/(97) \\
\hline usp13 & NT01EI_3810 & $c p \times P$ & 480 & 3 & 63 & 415/(86) \\
\hline
\end{tabular}

US, Upstream; DS, Downstream; ORF, Open reading frame.

E. coli culture by a QIAprep Spin Miniprep Kit (Qiagen) and digested with appropriate restriction enzymes respective to the inserts. The in-frame deletion fragments were ligated into the linearized pMEG-375 vector using T4 DNA Ligase (NEB) at $16^{\circ} \mathrm{C}$ overnight. E. coli CC118 $\lambda$ pir was transformed by electroporation and plated on LB agar plus ampicillin. Resulting plasmids were isolated from the colonies and confirmed by size, restriction enzyme digestion, and finally by sequencing. The resulting plasmids named as $\mathrm{pEi} \Delta u$ usp02-10 and $\mathrm{pEi} \Delta u$ usp 13 were transferred into E. coli SM10 pir or BW19851 by chemical transformation and mobilized into E. ictaluri WT by conjugation. First integration was selected by ampicillin, and ampicillin resistant colonies were propagated on BHI agar to allow for the second crossover allelic exchange. After this step, colonies were streaked on counter selective BHI plates with $5 \%$ sucrose, 0.35\% mannitol, and colistin to allow loss of pMEG-375. Potential mutant colonies were tested for ampicillin sensitivity to ensure the loss of the plasmid, confirmed by PCR, and sequencing.

\section{Construction of Bioluminescent USP Mutants}

The constructed USP mutants were made bioluminescence using pAKgfplux 1 plasmid as described previously (Karsi and Lawrence, 2007). Briefly, the overnight culture of both recipient

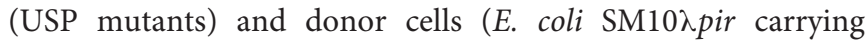
pAKgfplux 1 ) were mixed at 1:2 ratio (donor : recipient) and centrifuged briefly. Pellet was transferred onto sterile $0.45 \mu \mathrm{M}$ filter papers placed on a $\mathrm{BHI}$ agar and incubated at $30^{\circ} \mathrm{C}$ for $24 \mathrm{~h}$. Bacteria on the filter paper were collected in BHI broth with ampicillin and colistin and then spread on BHI plates containing ampicillin and colistin. After incubation at $30^{\circ} \mathrm{C}$ for $24-48 \mathrm{~h}$, ampicillin resistant bioluminescent $E$. ictaluri colonies carrying pAKgfplux 1 appeared on plates.

\section{Growth Kinetics of the E. ictaluri USP Mutants in BHI}

Growth kinetics of the ten E. ictaluri USP mutants was compared to E. ictaluri WT in BHI medium as previously described (Abdelhamed et al., 2016). Each bacterial strain had four replicates. Overnight cultures were grown in a shaking incubator at $30^{\circ} \mathrm{C}$ for $18 \mathrm{~h}$. The optical densities $\left(\mathrm{OD}_{600}\right)$ were measured, and adjusted volumes were added to $15 \mathrm{ml}$ fresh BHI (1:100 dilution). Cultures were grown for $24 \mathrm{~h}$ by sampling and measuring $\mathrm{OD}_{600}$ values at $2,4,8,12$, and $20 \mathrm{~h}$.

\section{Survival of E. ictaluri USP Mutants in Low pH Stress}

Survival of bioluminescent USP mutants and EiWT was determined under acidic stress ( $\mathrm{pH}$ 5.5) as previously described (Seifart Gomes et al., 2011). Bacteria were cultured overnight, and $\mathrm{OD}_{600}$ values were used to adjust culture volumes. The experiment was performed in 96 well black plates with four replicates at acidic and neutral $\mathrm{pH}$. For each well, $5 \mu \mathrm{l}$ of bacteria were inoculated into $195 \mu \mathrm{l}$ of BHI broth plus ampicillin and colistin. The plates were incubated in Cytation 5 Cell Imaging Multi-Mode Reader (BioTek, Winooski, VT, United States), and the photon emissions were collected for $3 \mathrm{~h}$ at $30^{\circ} \mathrm{C}$. Bioluminescence imaging (BLI) of the 96-well plate was taken using IVIS 100 Series (Caliper Corporation, Hopkinton, MA, United States). Three independent experiments were done and used for statistical analysis.

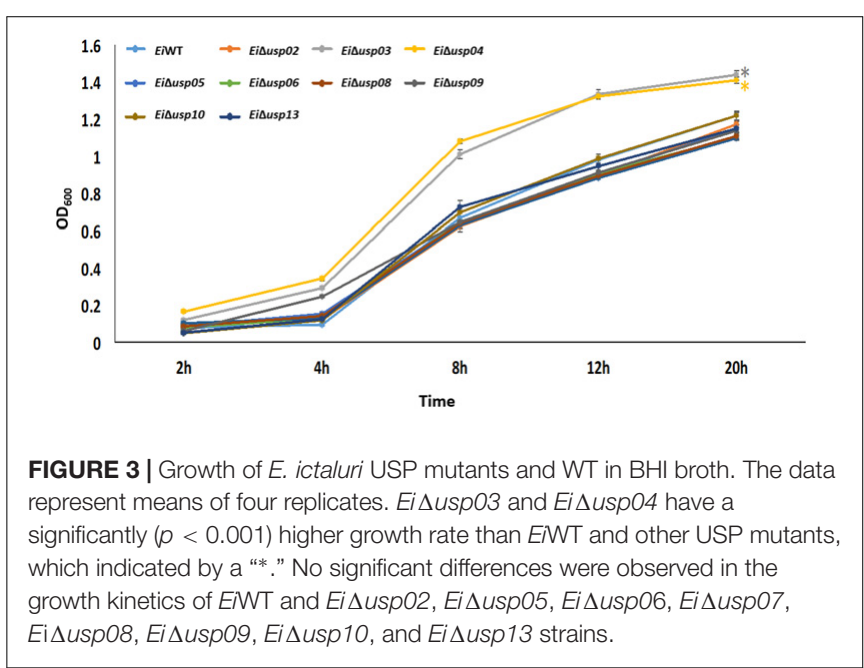




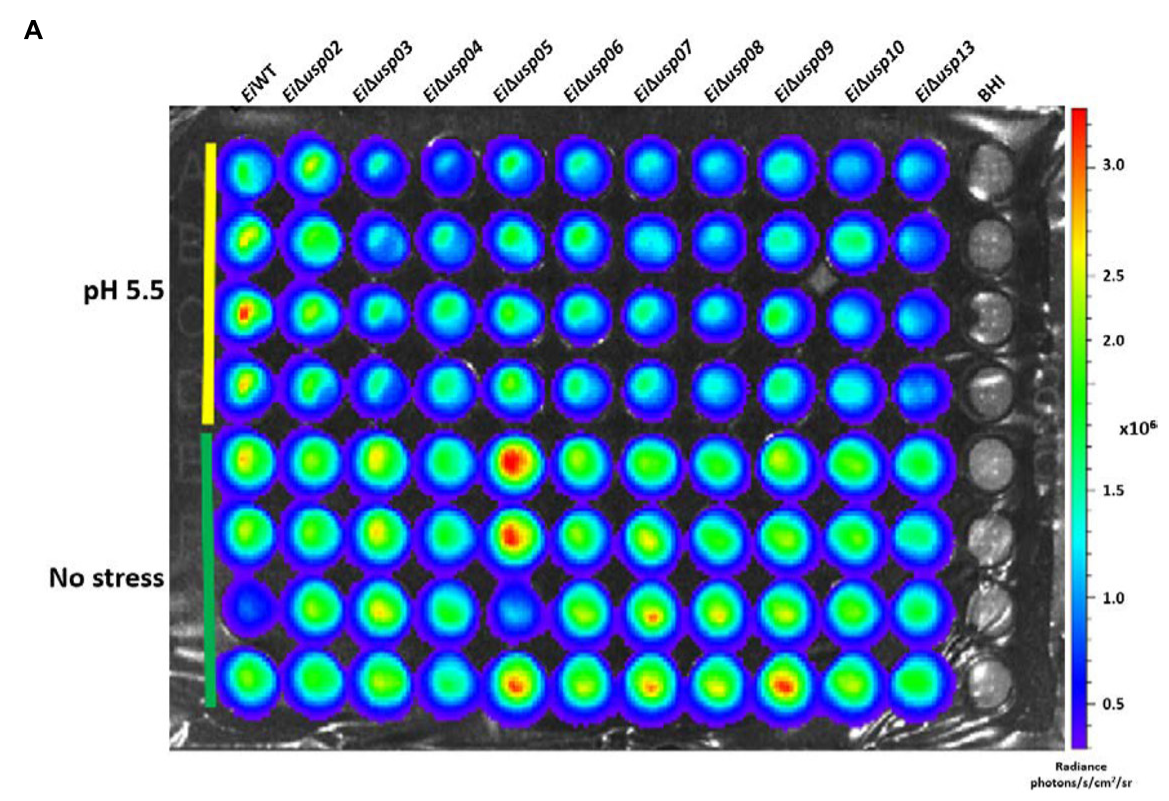

B

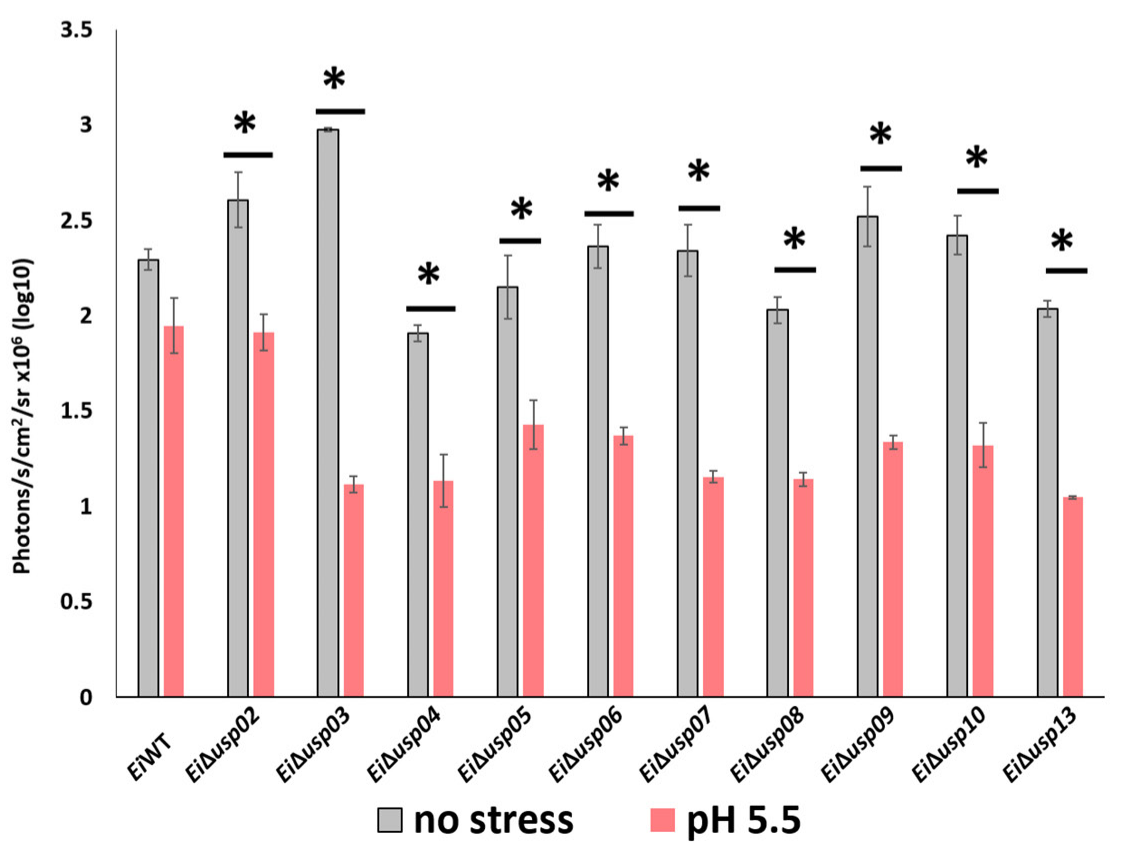

FIGURE 4 | The survival assay of E. ictaluri WT and USP mutants in $\mathrm{pH}$ 5.5. (A) Each strain had four replicates (column A-D). Strains start with E. ictaluri WT, Ei $\Delta$ usp02-13 and BHI control. (B) The bars show the difference between bioluminescence of USP mutants and WT. *indicates a significant difference between stress and non-stress at $P<0.01$.

\section{Survival of E. ictaluri USP Mutants in Oxidative Stress}

The survival of the ten USP mutants in BHI supplemented with $0.1 \%$ of $\mathrm{H}_{2} \mathrm{O}_{2}$ were determined as previously described (Seifart Gomes et al., 2011). The experiment was performed in 96 well plates with four replicates under oxidative stress and normal conditions. The plates were incubated in Cytation 5 Cell Imaging Multi-Mode Reader, and the photon emissions were collected for $3 \mathrm{~h}$ at $30^{\circ} \mathrm{C}$.

\section{Virulence and Efficacy of E. ictaluri USP Mutants in Catfish Fingerlings}

Virulence and vaccine efficacy trials were conducted as reported by our group (Karsi et al., 2009). Approximately 720 channel catfish fingerlings (average: $13.728 \mathrm{~cm}, 10.544 \mathrm{~g}$ ) were stocked into 36 tanks at a rate of 20 fish/tank. Tanks were divided into twelve groups with three replicate tanks each group. The experiment included 10 E. ictaluri USP mutants, positive control (EiWT), and negative control (BHI exposed). After 1 week of 


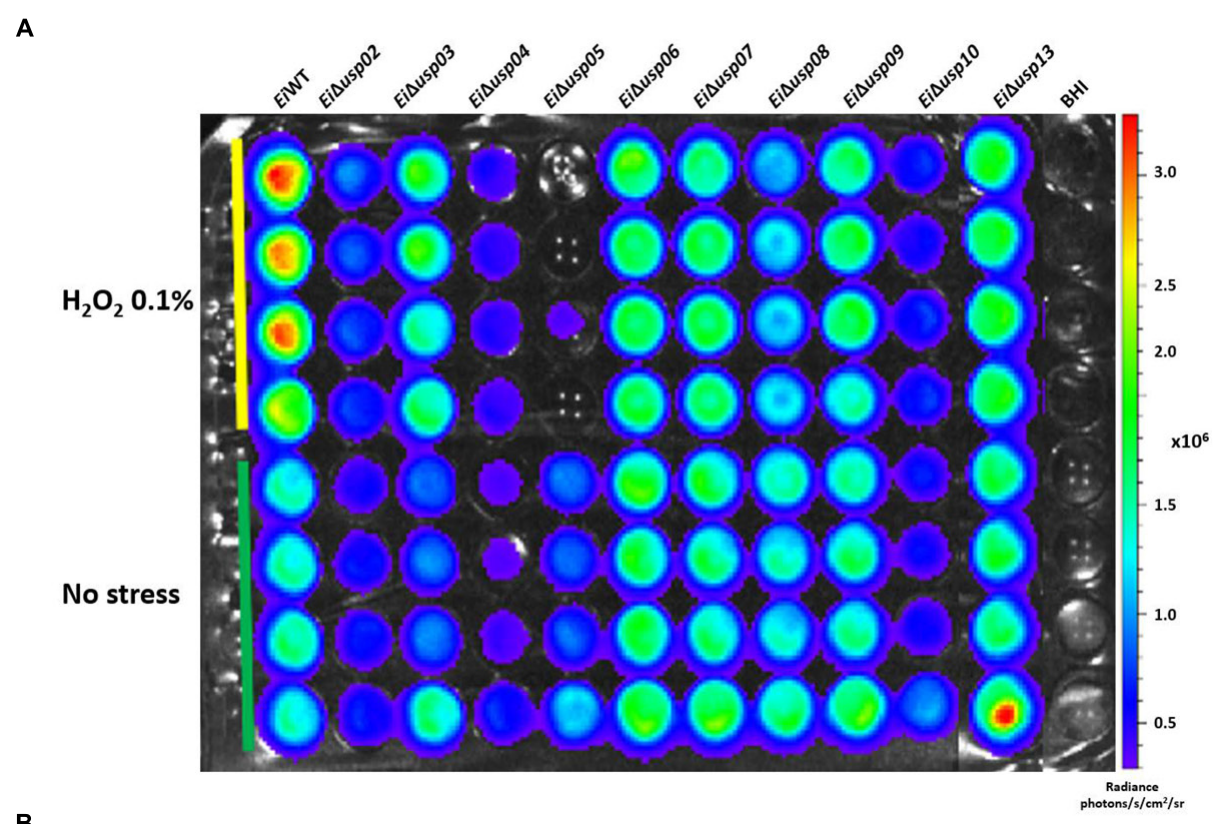

B

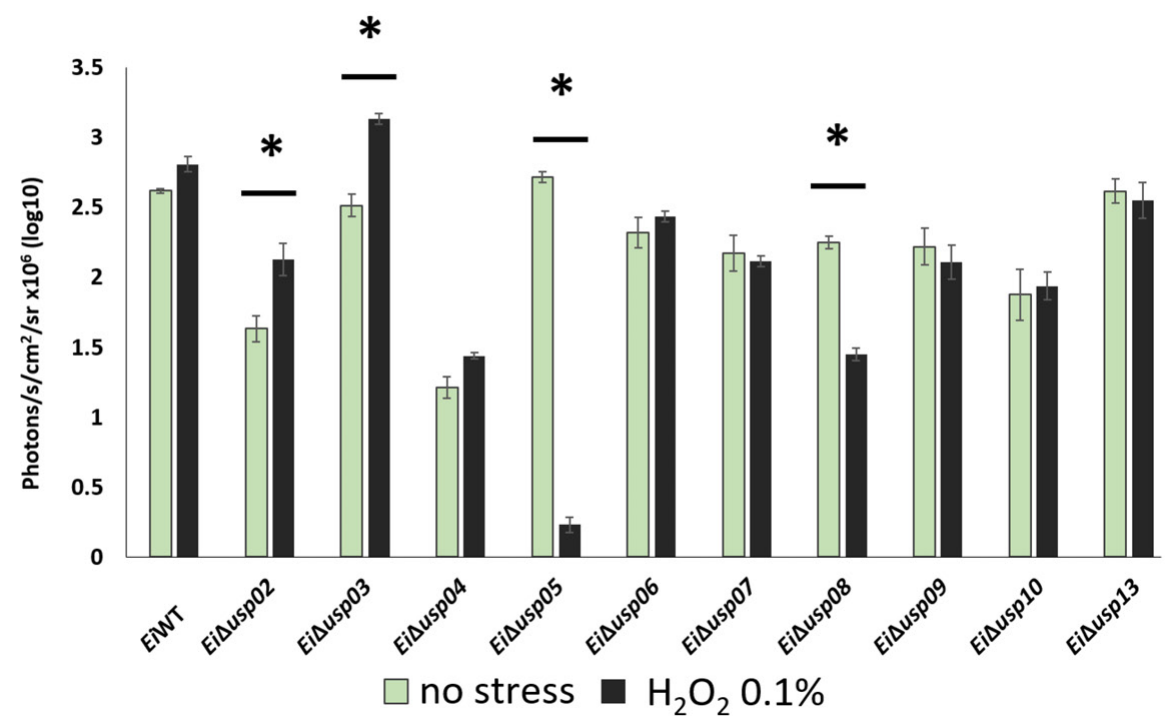

FIGURE 5 | The survival assay of E. ictaluri WT and USP mutants exposed to $0.1 \% \mathrm{H}_{2} \mathrm{O}_{2}$. (A) Each strain had four replicates (column A-D). Strains start with E. ictaluri WT, Ei $\Delta$ usp02-13 and BHI control. (B) The bars show the difference between bioluminescence of USP mutants and WT. *indicates a significant difference between stress and non-stress at $P<0.01$.

acclimation, fish were challenged/vaccinated by immersion with $1.3 \times 10^{7} \mathrm{CFU} / \mathrm{ml}$ water for $1 \mathrm{~h}$. Mortalities were recorded daily for 21 days, and the mean percent mortalities were calculated for each treatment group. Protective properties of USP mutants against EiWT infection was determined by challenging vaccinated catfish with $E i W T\left(2.8 \times 10^{7} \mathrm{CFU} / \mathrm{ml}\right.$ water $)$. Fish mortalities were recorded daily, and the percent mortality was calculated for each group.

\section{Statistical Analysis}

For the growth kinetic experiment, significant differences between EiWT and USP mutants were determined by
Student's $t$-test. For acid and hydrogen peroxide assays, photon counts were $\log _{10}$ transformed $t$-tests were conducted. Percent reduction in bioluminescence was calculated by dividing mean photon emissions of USPs to mean photon emission of EiWT. For fish experiments, percent mortalities were arcsine transformed, and analysis of variance (ANOVA) was carried out using PROC GLM of SAS v9.4 (SAS Institute, Inc., Cary, NC, United States). In virulence/vaccination trial, the percent mortalities of USP mutants were compared to that of EiWT, while in efficacy trail, the comparisons were made to the sham-vaccinated group at the alpha level of 0.05 . 


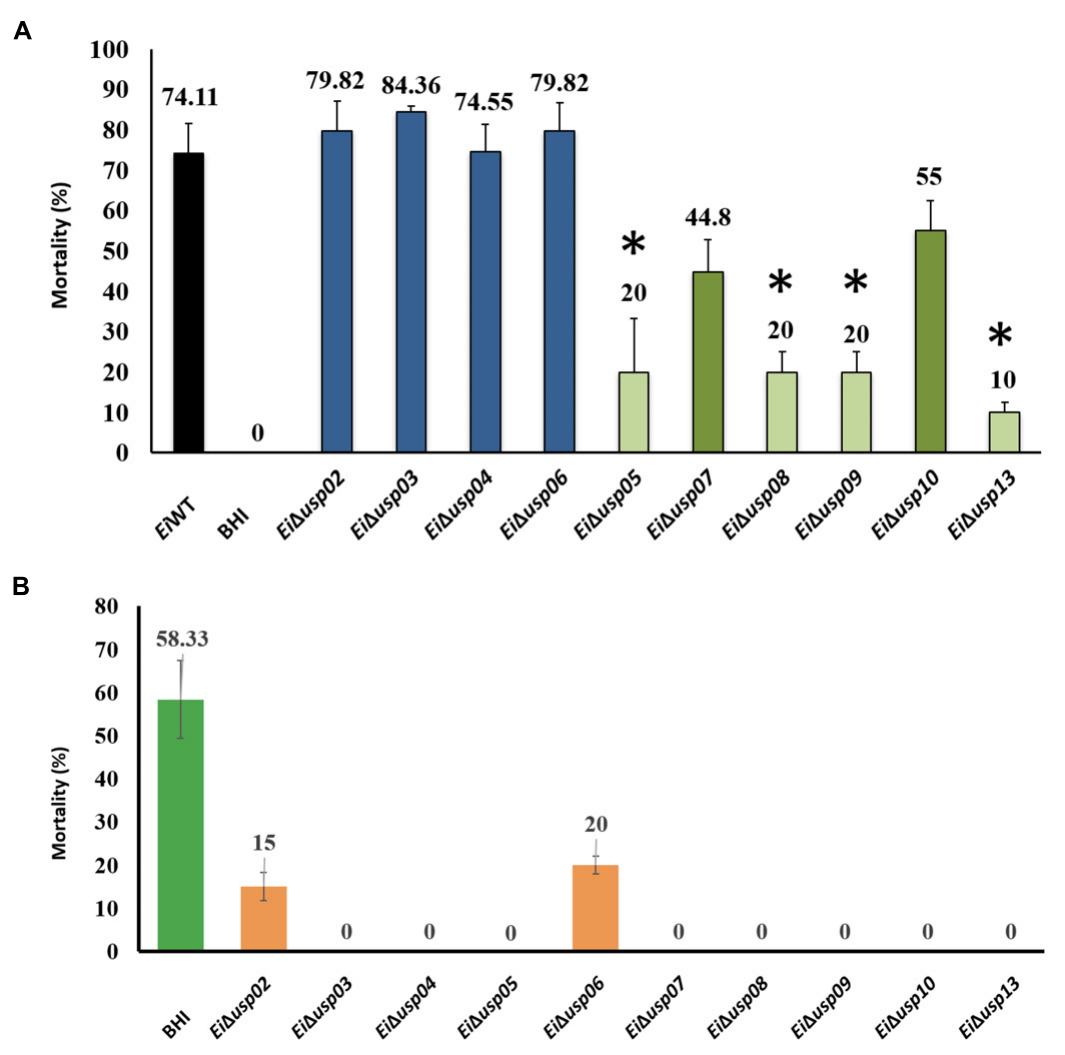

FIGURE 6 | Vaccination tests of USP mutants in channel catfish fingerlings. (A) Percent mortalities seen after vaccination. (B) Percent mortalities of channel catfish fingerlings immunized with USP mutants and re-challenged with E. ictaluri wild-type 3 weeks post immunization. *indicates significant differences between mutant and $\mathrm{WT}$ at $P<0.01$.

\section{RESULTS}

\section{Construction of the E. ictaluri USP Mutants}

Thirteen universal stress proteins were identified in the E. ictaluri genome (Williams et al., 2012) by sequence similarity (Figure 1). They were scattered through the chromosome, and no operon structure was observed. We were able to delete 10 E. ictaluri usp genes in-frame, and mutants were verified by PCR (Figure 2) as well as sequencing. Properties of wild-type and mutated usp genes are shown in Table 3. In-frame deletion resulted in removal of a large portion (86-99\%) of the wild-type usp genes (Table 3).

\section{Growth Kinetics of the E. ictaluri USP Mutants in BHI}

The growth of EiWT and USP mutants in BHI broth indicated

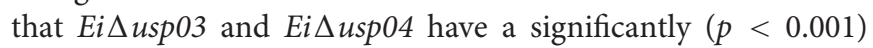
higher growth rate than EiWT. After $20 \mathrm{~h}$ incubation, the

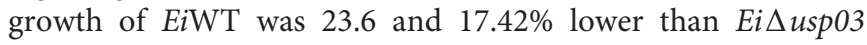
and Ei $\Delta$ usp04, respectively (Figure 3). Whereas, no significant differences were observed in the growth kinetics of EiWT

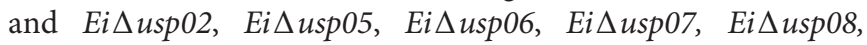

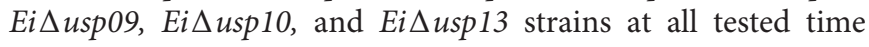
points.

\section{Survival of $E$. ictaluri USP Mutants in Low pH Stress}

To evaluate the role of usp genes in survival and growth of E. ictaluri at low $\mathrm{pH}$, mutants and EiWT were exposed to acidic $\mathrm{pH}$ (5.5) and neutral $\mathrm{pH}$, and bacterial growth (quantified by bioluminescent signal) were calculated. The growth rate (photon numbers) of the all USP mutants in low $\mathrm{pH}$ was significantly lower than that of in neutral $\mathrm{pH}$. In contrast, the growth of EiWT at low $\mathrm{pH}$ was lower but not significant (Figures 4A,B). The strongest effect of low $\mathrm{pH}$ was observed in Ei $\Delta u s p 03$ growth (62\% reduction) compared to EiWT. The order of susceptibility of USP mutants in low $\mathrm{pH}$ as follows: $\Delta$ usp03 > u usp07 > $\Delta$ usp $13>\Delta$ usp09 $>\Delta$ usp $10>\Delta$ usp08 $>$ $\Delta$ usp06 $>\Delta$ usp04 $>\Delta$ usp05 $>\Delta$ usp02. The reduced growth of the USP mutants indicates that usp genes contribute E. ictaluri survival under acidic conditions.

\section{Survival of E. ictaluri USP Mutants in Oxidative Stress}

Exposure to hydrogen peroxide $\left(0.1 \% \quad \mathrm{H}_{2} \mathrm{O}_{2}\right)$ significantly reduced growth of Ei $\Delta u s p 05$ and Ei $\Delta u s p 08$ compared to no stress group (91 and 35\% reduction, respectively), while

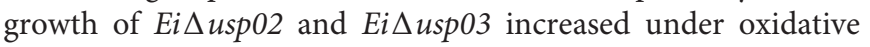




\begin{tabular}{|c|c|c|c|c|}
\hline \multirow[b]{2}{*}{ Mutant ID $\downarrow$} & \multicolumn{2}{|c|}{ Survival (\%) } & \multicolumn{2}{|c|}{ Vaccination (\%) } \\
\hline & $\mathrm{pH}$ & $\mathrm{H}_{2} \mathrm{O}_{2}$ & Virulence & Efficacy \\
\hline Eisusp02 & $\downarrow 27$ & $\uparrow 30$ & 80 & 15 \\
\hline Eisusp03 & $\downarrow 62$ & $\uparrow 25$ & 84 & 0 \\
\hline Eisusp04 & $\downarrow 40$ & $\uparrow 19$ & 75 & 0 \\
\hline Eisusp05 & $\downarrow 34$ & $\downarrow 91$ & 20 & 0 \\
\hline 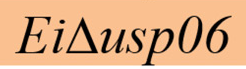 & $\downarrow 42$ & $\uparrow 5$ & 80 & 20 \\
\hline Eisusp07 & $\downarrow 51$ & $\downarrow 3$ & 44 & 0 \\
\hline Eidusp08 & $\downarrow 44$ & $\downarrow 35$ & 20 & 0 \\
\hline Eisusp09 & $\downarrow 47$ & $\downarrow 5$ & 20 & 0 \\
\hline Eiduspl0 & $\downarrow 45$ & ^3 & 55 & 0 \\
\hline Eisusp 13 & $\downarrow 49$ & $\downarrow 2$ & 10 & 0 \\
\hline $\begin{array}{l}(\Downarrow) \text { Reducti } \\
\text { Mortality sho }\end{array}$ & $\begin{array}{l}\text { (个) inc } \\
y \% \text { in }\end{array}$ & $\begin{array}{l}\% \text { in } k \\
\text { ation }\end{array}$ & $\begin{array}{l}\text { inescence } \\
\text { fficacy }\end{array}$ & \\
\hline
\end{tabular}

FIGURE 7 | Overall summary of results. Survival percent under acidic $(\mathrm{pH})$ and oxidative stress $\left(\mathrm{H}_{2} \mathrm{O}_{2}\right)$ conditions was calculated based on changes in bioluminescence signal. The downward direction arrow indicates reduction in survival percent between mutant strain compared with wild type. The upward direction indicates increase in survival percent. Virulence percent is based on catfish mortality after immersion challenge with USP mutant strains. Efficacy perecent is based of mortality after re-challenge the immunized fish with E. ictaluri WT at 21 day post-immunization.

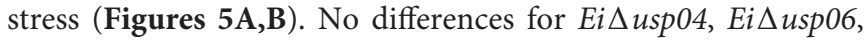

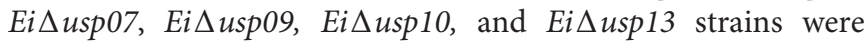
observed.

\section{Virulence and Efficacy of E. ictaluri USP Mutants in Catfish Fingerlings}

The percent mortalities in catfish challenged with Ei $\Delta$ usp05,

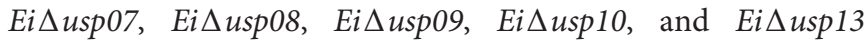
were significantly lower than that of $\operatorname{EiWT}(20,44.8$, $20,20,55$, and $10 \%$ vs. $74.1 \%$ mortality, respectively) (Figure 6A). In contrast, no significant differences between

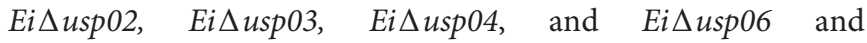
EiWT $(79.8,84.4,74.6$, and $79.82 \%$ vs. $74.1 \%$ mortality, respectively) were observed (Figure 6A). The order of attenuation in the 10 USP mutants are as following:

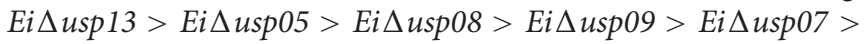
Ei $\Delta u s p 10>E i \Delta u s p 04>E i \Delta u s p 06>E i \Delta u s p 02>$ Ei $\Delta u s p 03$.

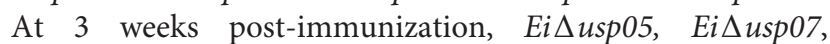

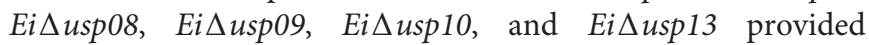
significant protection against EiWT challenges (no mortalities; $p<0.01)$ compared to sham-vaccinated fish (58.33\% mortality) (Figure 6B). Although immunization with Ei $\Delta u s p 03$ and Ei $\Delta$ usp04 protected catfish significantly, they were not safe.

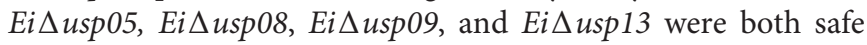
and protective among all USP mutants.

Figure 7 provides overall summary of the results.

\section{DISCUSSION}

Several previous studies reported that universal stress proteins (USPs) play a role in different bacteria to respond to different stress conditions, such as heat, substrate starvation, exposure to antimicrobial agents, acidic stress, and oxidative stress (Seifart Gomes et al., 2011). The objective of this study was to determine the role of E. ictaluri usp genes in acidic and oxidative stresses as well as in virulence. Also, mutants' vaccine potentials were determined.

The uspA gene among usp genes has been studied in different bacterial strains. Deletion of the uspA genes resulted in decreased virulence in Salmonella typhimurium C5, Listeria monocytogenes, and Acinetobacter baumannii (Liu et al., 2007; Seifart Gomes et al., 2011; Elhosseiny et al., 2015). Also, uspA affected the host invasion and survival in Salmonella enterica and Mycobacterium tuberculosis (Hensel, 2009; HingleyWilson et al., 2010). In the present study, there were four usp genes (usp05, usp06, usp08, and usp09) with high similarity

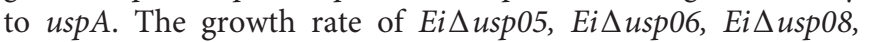
and Ei $\Delta$ usp09 were similar to E. ictaluri WT. However, Ei $\Delta u s p 05$ and Ei $\Delta u s p 08$ showed reduced growth in oxidative and acidic stresses compared to EiWT. Virulence data showed

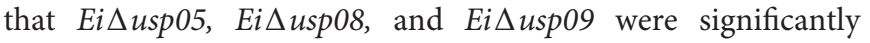
attenuated compared to E. ictaluri WT. However, Ei $\Delta$ usp06 was not attenuated. These results are consistent with a previous study in L. monocytogenes where not all uspA are involved 
in reduced virulence (Seifart Gomes et al., 2011). Previously, our group reported that transposon insertion mutants in usp05 reduced E. ictaluri virulence in catfish and provided better protection against ESC (Kalindamar, 2013). Additionally, expressions of usp05 were very high in response to host stress or high level of $\mathrm{H}_{2} \mathrm{O}_{2}$ in E. ictaluri (Akgul et al., 2018). The usp05 gene (uspA) is an important regulator of survival and virulence in many pathogens (Tkaczuk et al., 2013). In E. coli, uspA mutant caused a survival defect under a variety of growtharrested conditions, whereas overexpression induced growth in the growth-arrested state. Our data suggest that usp05, usp08, and usp09 are important virulence genes in E. ictaluri.

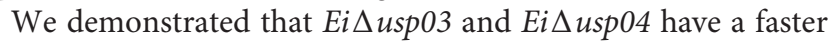
growth rate than EiWT and other USP mutants. However, lack of usp genes did not cause growth differences in Listeria monocytogenes (Seifart Gomes et al., 2011), E. coli (Nystrom and Neidhardt, 1993) or other bacteria when cultured in conventional media (Liu et al., 2007; Hingley-Wilson et al.,

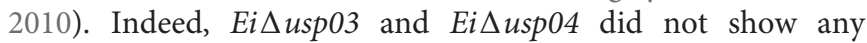
virulence attenuation in E. ictaluri, which was similar to USP mutant Rv2623 in Mycobacterium tuberculosis (HingleyWilson et al., 2010). This study suggested that usp genes might play a role in latency and persistence of chronic TB infection. We think that usp03 and usp04 are not involved in virulence but may play other roles in stress responses in E. ictaluri.

Edwardsiella ictaluri can survive and continue growth in up to $3 \mathrm{mM}$ of $\mathrm{H}_{2} \mathrm{O}_{2}$ and low acidic $\mathrm{pH}$ 5.5. When the USP mutants and EiWT exposed to low $\mathrm{pH}$, growth rates did not change significantly. As shown previously, L. monocytogenes ATP Binding USPs exhibited role in the response to acid stress during exponential growth phase (Tremonte et al., 2016).

Our results indicated that E. ictaluri usp07 contributes to virulence of E. ictaluri. Mortality was significantly decreased in the Ei $\Delta$ usp07 mutant compared to EiWT strain. The usp07 is a $K d p D$ protein, and it contains a $u s p A$ domain (Heermann et al., 2009a). We included whole $K d p D$ as $u s p 07$ because USP domain is located between the $N$-terminal sensor domain and $C$-terminal catalytic domain of this Osmo-sensitive $\mathrm{K}^{+}$channel histidine kinase. Mutant KdpD in Salmonella typhimurium is attenuated in animal infection model and macrophage survival experiments. It also promotes resistance to osmotic, oxidative and antimicrobial stresses (Alegado et al., 2011). $K d p D$ is also involved in oxidative-osmotic stress, response to host, and virulence (Freeman et al., 2013). In our gene expression study after host stress, usp07 showed a very high expression level (Akgul et al., 2018). It is important to note that usp07 involved in E. ictaluri virulence and acid stress response.

The usp13 was described as a universal stress protein and extra cytoplasmic adaptor protein $(C p x P)$ like protein (Williams et al., 2012). The usp13 (CpxP) is placed in the inner membrane with histidine kinase $C p x A$ and $C p x R$, a response regulator (Vogt and Raivio, 2012; Debnath et al., 2013). CpxP is the most highly inducible member of the Cpx regulon, and it has elevated expression in response to both envelope stress and entry into stationary phase growth (Motohashi et al., 1999; DiGiuseppe and Silhavy, 2003). The CPX system is important and required for virulence in both Gram-negative and -positive bacteria (Raju et al., 2012). Previously, we determined that E. ictaluri, usp13 is highly expressed when exposed low acidic $\mathrm{pH}$ (5.5) and the catfish invasion (Akgul et al., 2018). The usp13 $($ cpxP) is an essential regulator of cell membrane stress in bacteria during host infection. Therefore, it is involved in the virulence of $E$. ictaluri with a very high reduction in virulence (Figure 6).

The expression of E. coli usp genes is controlled by some effector proteins and signaling molecules, such as SOS repose proteins (Gustavsson et al., 2002; Kvint et al., 2003; Persson et al., 2007). However, mechanisms of USPs in other bacterial species are not known entirely. Overall our results are in line with studies from various species that USPs were crucial for protecting the cells from the damaging effects of reactive oxygen species (ROS) (Nachin et al., 2005; Liu et al., 2007; Seifart Gomes et al., 2011; Elhosseiny et al., 2015; Figure 7).

\section{CONCLUSION}

Our lab aims to develop live attenuated vaccines to protect catfish against E. ictaluri infections. Live attenuated bacterial should be both safe and confer full protection against wild-type infections.

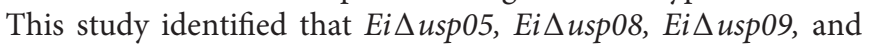
Ei $\Delta$ usp 13 strains have vaccine potential and further efforts, such as constructing double mutants to improve their safety, could be pursued. The data presented in this study display that USPs are essential for both stress physiology and pathogenesis in E. ictaluri.

\section{AUTHOR CONTRIBUTIONS}

$\mathrm{AK}$ and $\mathrm{ML}$ conceived the project and designed the experiments. AA, SN, SK, HT, and HA conducted the experiments. AA wrote the manuscript. SN, SK, HT, HA, ML, and AK reviewed the manuscript.

\section{FUNDING}

This project was supported by Agriculture and Food Research Initiative Competitive grant no. 2016-67015-24909 from the USDA National Institute of Food and Agriculture.

\section{ACKNOWLEDGMENTS}

We thank the Laboratory Animal Resources and Care at the College of Veterinary Medicine for providing the SPF channel catfish. AA was supported by a fellowship from the Republic of Turkey. 


\section{REFERENCES}

Abdelhamed, H., Lu, J., Lawrence, M. L., and Karsi, A. (2016). Involvement of tolQ and tolR genes in Edwardsiella ictaluri virulence. Microb. Pathog. 100, 90-94. doi: 10.1016/j.micpath.2016.09.011

Akgul, A., Akgul, A., Lawrence, M. L., and Karsi, A. (2018). Stress-related genes promote Edwardsiella ictaluri pathogenesis. PLoS One 13:e0194669. doi: 10. 1371/journal.pone.0194669

Alegado, R. A., Chin, C. Y., Monack, D. M., and Tan, M. W. (2011). The two-component sensor kinase $\mathrm{KdpD}$ is required for Salmonella typhimurium colonization of Caenorhabditis elegans and survival in macrophages. Cell. Microbiol. 13, 1618-1637. doi: 10.1111/j.1462-5822.2011.01645.x

Al-Maleki, A. R., Mariappan, V., Vellasamy, K. M., Shankar, E. M., Tay, S. T., and Vadivelu, J. (2014). Enhanced intracellular survival and epithelial cell adherence abilities of Burkholderia pseudomallei morphotypes are dependent on differential expression of virulence-associated proteins during midlogarithmic growth phase. J. Proteomics 106, 205-220. doi: 10.1016/j.jprot.2014. 04.005

Chaffin, D. O., Taylor, D., Skerrett, S. J., and Rubens, C. E. (2012). Changes in the Staphylococcus aureus transcriptome during early adaptation to the lung. PLoS One 7:e41329. doi: 10.1371/journal.pone.0041329

Chatterjee, S. S., Hossain, H., Otten, S., Kuenne, C., Kuchmina, K., Machata, S., et al. (2006). Intracellular gene expression profile of Listeria monocytogenes. Infect. Immun. 74, 1323-1338. doi: 10.1128/IAI.74.2.1323-1338.2006

Debnath, I., Norton, J. P., Barber, A. E., Ott, E. M., Dhakal, B. K., Kulesus, R. R., et al. (2013). The Cpx stress response system potentiates the fitness and virulence of uropathogenic Escherichia coli. Infect. Immun. 81, 1450-1459. doi: 10.1128/IAI.01213-12

DiGiuseppe, P. A., and Silhavy, T. J. (2003). Signal detection and target gene induction by the CpxRA two-component system. J. Bacteriol. 185, 2432-2440. doi: 10.1128/JB.185.8.2432-2440.2003

Dozois, C. M., Daigle, F., and Curtiss, R. III (2003). Identification of pathogenspecific and conserved genes expressed in vivo by an avian pathogenic Escherichia coli strain. Proc. Natl. Acad. Sci. U.S.A. 100, 247-252. doi: 10.1073/ pnas. 232686799

Elhosseiny, N. M., Amin, M. A., Yassin, A. S., and Attia, A. S. (2015). Acinetobacter baumannii universal stress protein A plays a pivotal role in stress response and is essential for pneumonia and sepsis pathogenesis. Int. J. Med. Microbiol. 305, 114-123. doi: 10.1016/j.ijmm.2014.11.008

Freeman, Z. N., Dorus, S., and Waterfield, N. R. (2013). The KdpD/KdpE twocomponent system: integrating $\mathrm{K}+$ Homeostasis and virulence. PLoS Pathog. 9:e1003201. doi: 10.1371/journal.ppat.1003201

Gustavsson, N., Diez, A., and Nystrom, T. (2002). The universal stress protein paralogues of Escherichia coli are coordinately regulated and co-operate in the defence against DNA damage. Mol. Microbiol. 43, 107-117. doi: 10.1046/j.13652958.2002.02720.x

Heermann, R., Lippert, M.-L., and Jung, K. (2009a). Domain swapping reveals that the $\mathrm{N}$-terminal domain of the sensor kinase $\mathrm{KdpD}$ in Escherichia coli is important for signaling. BMC Microbiol. 9:133. doi: 10.1186/14712180-9-133

Heermann, R., Weber, A., Mayer, B., Ott, M., Hauser, E., Gabriel, G., et al. (2009b). The universal stress protein UspC scaffolds the KdpD/KdpE signaling cascade of Escherichia coli under salt stress. J. Mol. Biol. 386, 134-148. doi: 10.1016/j. jmb.2008.12.007

Hensel, M. (2009). "Secreted proteins and virulence in Salmonella enterica", in Bacterial Secreted Proteins: Secretory Mechanisms and Role in Pathogenesis, ed. K. Wooldridge (Nottingham: Caister Academic Press).

Herrero, M., de Lorenzo, V., and Timmis, K. N. (1990). Transposon vectors containing non-antibiotic resistance selection markers for cloning and stable chromosomal insertion of foreign genes in Gram-negative bacteria. J. Bacteriol. 172, 6557-6567. doi: 10.1128/jb.172.11.6557-6567. 1990

Hingley-Wilson, S. M., Lougheed, K. E., Ferguson, K., Leiva, S., and Williams, H. D. (2010). Individual Mycobacterium tuberculosis universal stress protein homologues are dispensable in vitro. Tuberculosis 90, 236-244. doi: 10.1016/ j.tube.2010.03.013
Horton, R. M., Cai, Z. L., Ho, S. N., and Pease, L. R. (1990). Gene splicing by overlap extension: tailor-made genes using the polymerase chain reaction. Biotechniques 8, 528-535.

Kalindamar, S. (2013). Identification of the Edwardsiella Ictaluri Genes Causing Impaired Growth in Complex Medium. Master thesis, Mississippi State University, Starkville, MS.

Karsi, A., Gulsoy, N., Corb, E., Dumpala, P. R., and Lawrence, M. L. (2009). Highthroughput bioluminescence-based mutant screening strategy for identification of bacterial virulence genes. Appl. Environ. Microbiol. 75, 2166-2175. doi: 10. 1128/AEM.02449-08

Karsi, A., and Lawrence, M. L. (2007). Broad host range fluorescence and bioluminescence expression vectors for gram-negative bacteria. Plasmid 57, 286-295. doi: 10.1016/j.plasmid.2006.11.002

Karsi, A., Menanteau-Ledouble, S., and Lawrence, M. L. (2006). Development of bioluminescent Edwardsiella ictaluri for noninvasive disease monitoring. FEMS Microbiol. Lett. 260, 216-223. doi: 10.1111/j.1574-6968. 2006.00310.x

Kvint, K., Nachin, L., Diez, A., and Nyström, T. (2003). The bacterial universal stress protein: function and regulation. Curr. Opin. Microbiol. 6, 140-145. doi: 10.1016/S1369-5274(03)00025-0

Lawrence, M. L., Cooper, R. K., and Thune, R. L. (1997). Attenuation, persistence, and vaccine potential of an Edwardsiella ictaluri purA mutant. Infect. Immun. 65, 4642-4651.

Liu, W.-T., Karavolos, M. H., Bulmer, D. M., Allaoui, A., Hormaeche, R. D., Lee, J. J., et al. (2007). Role of the universal stress protein UspA of Salmonella in growth arrest, stress and virulence. Microb. Pathog. 42, 2-10. doi: 10.1016/j. micpath.2006.09.002

Metcalf, W. W., Jiang, W., and Wanner, B. L. (1994). Use of the rep technique for allele replacement to construct new Eschericia coli hosts for maintenance of R6K gamma origin plasmids at different copy numbers. Gene 138, 1-7. doi: 10.1016/0378-1119(94)90776-5

Miller, V. L., and Mekalanos, J. J. (1988). A novel suicide vector and its use in construction of insertion mutations: osmoregulation of outer membrane proteins and virulence determinants in Vibrio cholerae requires toxR. J. Bacteriol. 170, 2575-2583.

Motohashi, K., Watanabe, Y., Yohda, M., and Yoshida, M. (1999). Heatinactivated proteins are rescued by the DnaK.J-GrpE set and ClpB chaperones. Proc. Natl. Acad. Sci. U.S.A. 96, 7184-7189. doi: 10.1073/pnas. 96.13.7184

Nachin, L., Nannmark, U., and Nystrom, T. (2005). Differential roles of the universal stress proteins of Escherichia coli in oxidative stress resistance, adhesion, and motility. J. Bacteriol. 187, 6265-6272. doi: 10.1128/JB.187.18. 6265-6272.2005

Nystrom, T., and Neidhardt, F. C. (1993). Isolation and properties of a mutant of Escherichia coli with an insertional inactivation of the uspA gene, which encodes a universal stress protein. J. Bacteriol. 175, 3949-3956. doi: 10.1128/jb.175.13. 3949-3956.1993

Persson, O., Valadi, A., Nystrom, T., and Farewell, A. (2007). Metabolic control of the Escherichia coli universal stress protein response through fructose-6-phosphate. Mol. Microbiol. 65, 968-978. doi: 10.1111/j.1365-2958.2007.05838.x

Raju, R. M., Goldberg, A. L., and Rubin, E. J. (2012). Bacterial proteolytic complexes as therapeutic targets. Nat. Rev. Drug Discov. 11, 777-789. doi: 10.1038/nrd3846

Seifart Gomes, C., Izar, B., Pazan, F., Mohamed, W., Mraheil, M. A., Mukherjee, K., et al. (2011). Universal stress proteins are important for oxidative and acid stress resistance and growth of Listeria monocytogenes EGD-e In vitro and In vivo. PLoS One 6:e24965. doi: 10.1371/journal.pone.0024965

Siegele, D. A. (2005). Universal stress proteins in Escherichia coli. J. Bacteriol. 187, 6253-6254. doi: 10.1128/JB.187.18.6253-6254.2005

Tkaczuk, K. L., Shumilin, A., Chruszcz, M., Evdokimova, E., Savchenko, A., and Minor, W. (2013). Structural and functional insight into the universal stress protein family. Evol. Appl. 6, 434-449. doi: 10.1111/eva.12057

Tremonte, P., Succi, M., Coppola, R., Sorrentino, E., Tipaldi, L., Picariello, G., et al. (2016). Homology-based modeling of universal stress protein from Listeria innocua Up-regulated under acid stress conditions. Front. Microbiol. 7:1998. doi: $10.3389 /$ fmicb.2016.01998 
Tu, T. D., Haesebrouck, F., Nguyen, A. T., Sorgeloos, P., Baele, M., and Decostere, A. (2008). Antimicrobial susceptibility pattern of Edwardsiella ictaluri isolates from natural outbreaks of bacillary necrosis of Pangasianodon hypophthalmus in Vietnam. Microb. Drug Resist. 14, 311-316. doi: 10.1089/mdr. 2008.0848

USDA (2014). Development of Approaches to Prevent and Ameliorate Diseases of Catfish (Agricultural Research Service Annual Report). Washington, DC: United States Department of Agriculture.

Vogt, S. L., and Raivio, T. L. (2012). Just scratching the surface: an expanding view of the Cpx envelope stress response. FEMS Microbiol. Lett. 326, 2-11. doi: 10.1111/j.1574-6968.2011.02406.x

Williams, M. L., Gillaspy, A. F., Dyer, D. W., Thune, R. L., Waldbieser, G. C., Schuster, S. C., et al. (2012). Genome sequence of Edwardsiella ictaluri 93-146, a strain associated with a natural channel catfish outbreak of enteric septicemia of catfish. J. Bacteriol. 194, 740-741. doi: 10.1128/JB 06522-11

Conflict of Interest Statement: The authors declare that the research was conducted in the absence of any commercial or financial relationships that could be construed as a potential conflict of interest.

Copyright (C) 2018 Akgul, Nho, Kalindamar, Tekedar, Abdalhamed, Lawrence and Karsi. This is an open-access article distributed under the terms of the Creative Commons Attribution License (CC BY). The use, distribution or reproduction in other forums is permitted, provided the original author(s) and the copyright owner(s) are credited and that the original publication in this journal is cited, in accordance with accepted academic practice. No use, distribution or reproduction is permitted which does not comply with these terms. 